\title{
Tecnura
}

\section{Regional Intellectual Wealth and Sustainable Development in Colombia}

\section{Riqueza intelectual territorial y desarrollo sustentable en Colombia}

\author{
Carlos Hildebrando Fonseca Zárate ${ }^{(D)}$, Juan Carlos García Ubaque (iD)2, Paula Fernanda \\ García-Benitez ${ }^{\text {ID } 3}$
}

Fecha de Recepción: 23 de septiembre de 2020

Fecha de Aceptación: 24 de febrero de 2020

Cómo citar: Fonseca-Zárate., C.H. García-Ubaque., J.C. y García-Benitez., P.F. (2021). Saberes y acciones de jóvenes del medio rural frente a problemas ambientales. Tecnura, 25(68), 15-27. https: / / doi.org/10.14483/22487638.17389

\begin{abstract}
Context: There is a growing concern with the economic consumption and unlimited accumulation model because improvement in some parameters implies that others are negatively affected. There is a need for more intellectual wealth, not only oriented towards the market, but also towards engineering and technology.

Methodology: To measure natural/environmental, human, intellectual, public/institutional, and private wealth, the basic results of the Índice de desarrollo territorial sustentable (IDTS, spanish acronyms) are used, which is formed by 60 variables. With data from the 2000-2010 period, the relationship between the 5 types of wealth and sustainability is analyzed using principal component analysis.

Results: At the municipal and departmental levels, the direction of the natural and environmental wealth was found to be opposite direction to the other four. The distance between the different types of wealth ended up being important, and it increases with the IDTS.

Conclusions: The development model followed by Colombia is negatively affecting the natural and environmental wealth and as so is unsustainable. Neither research nor innovation are making adequate use of the natural resources at municipal level, and autonomous regional corporations may be ineffective against the inadequate use of this wealth. It is imperative to modify this exploitation model and reduce the distance between the five types of wealth. Although it is necessary to adopt and develop engineering and technology adequate to biodiversity and tropical geography, this is not enough; substantial social and institutional innovation are also needed in the face of a complex, uncertain, and dizzying technological reality, which is also inequitable at the social and interregional scale.
\end{abstract}

Financing: This project was self-funded.

Keywords: preservation of natural resources, sustainable development, ecodevelopment, sustainable development indicators, environmental policy.

\footnotetext{
${ }^{1}$ Civil Engineer, $\mathrm{PhD}$ in Geography. Head of the Simbiosis Corporation. Bogotá, Colombia. Email: carlosfonsecaz@gmail.com

${ }^{2}$ Master's Degree and PhD in Public Health. Titular professor Universidad Nacional de Colombia, Public Health department. Bogotá, Colombia. Email: jcgarciau@unal.edu.co

${ }^{3}$ Business Administration, Universidad Nacional de Colombia; Economist, Universidad de los Andes. MSc in Public Health, Universidad de los Andes (C). Bogotá, Colombia. Email: pf.garcia10@uniandes.edu.co
} 


\section{Resumen}

Contexto: Hay preocupación creciente con el modelo económico de consumo y acumulación ilimitados, pues la mejoría de algunos parámetros implica afectar otros negativamente. Se requiere mayor riqueza intelectual, que no esté solo orientada al mercado, especialmente en las ingenierías y tecnologías.

Metodología: Para medir las riquezas: natural/ambiental, humana, intelectual, pública/institucional y privada, se utilizan los resultados básicos del índice de desarrollo territorial sustentable (IDTS), conformado por 60 variables. Con información del periodo 2000-2010, se analiza la relación entre las cinco riquezas y la sustentabilidad utilizando análisis de componentes principales.

Resultados: tras el análisis, se encontró que, a nivel municipal y departamental, la riqueza natural y ambiental va en dirección contraria a las otras cuatro. La distancia entre los diferentes tipos de riqueza resultó importante y crece con el IDTS.

Conclusiones: El modelo de desarrollo que Colombia está siguiendo está afectando negativamente la riqueza natural y ambiental y resulta insostenible. La investigación e innovación no están haciendo uso adecuado de los recursos y atributos naturales a nivel municipal y las corporaciones autónomas regionales pueden ser ineficaces frente al uso inadecuado de esta riqueza. Es imperativo modificar este modelo de aprovechamiento y disminuir la distancia entre los cinco tipos de riqueza. Aunque es necesario adoptar ydesarrollar ingeniería y tecnologías adecuadas a la biodiversidad y geografía tropical, esto no es suficiente; se requiere innovación social e institucional sustantivas, de cara a una realidad tecnológica compleja, incierta y vertiginosa, al tiempo que inequitativa a escala social e interregional.

Financiamiento: Este proyecto contó con recursos propios.

Palabras clave: conservación de los recursos naturales, desarrollo sostenible, ecodesarrollo, indicadores de desarrollo sostenible, política ambiental.

\section{Table of Contents}

\section{INTRODUCTION}

The paradigm of consumption and unlimited accumulation without restrictions goes against ethics and human dignity (Sen, 2001, Castells \& Himanen, 2016). It also compromises the survival of 
natural ecosystems, whose value in terms of their multiple goods and services surpasses the global GDP (Costanza et al., 2014). Additionally, responses to this issue have focused on the idea of sustainable development and mechanisms such as retributive rates. However, this vision tends to be focused on one sector only and is fragmented, which emphasizes the concept of unlimited economic growth (Dasgupta, 2013, Shindell, 2015, Spaiser et al., 2017, Selomane et al., 2019). Nevertheless, it has been demonstrated that classical economic paradigms such as perfect competition, rational consumption, perfect information, and diminishing returns have no theoretical support (Romer,1986, Lucas, 1989, Stiglitz, 2002,Krugman, 2011).

(Ocampo, 2021) states that intragenerational and intergenerational equity aspects are at play, as poorer people are the most affected by environmental degradation, with strongerconsequences to the rural poor. He defines development as the ability of the countries or regions to diversify their production matrix, which agrees with (Hausmann, 2006) on the fact that the sophistication of exports is the main indicator of development. This limited scope, about the concept of development, which overemphasizes economic aspects, has generated a strong "post-development" school of thought (Escobar, 2008) and has replaced the term with the alternative "good living".

That is why the idea of development as a complex, multilevel, and multidimensional process has resurfaced, and it considers how it is built by both people and communities, as well as territories and nations, that are seek a solidary and collective future, a "better life" shared with nature. In other words, it is a continuous process of transitioning from an antrophocentric civilization with a high social and ecological debt to an ecocentric culture (Raworth, 2014).

Taking all of this into account, in this research, we used the Sustainable Territorial Development Index (Índice de desarrollo territorial sustentable, IDTS), which balances five types of wealth that should harmonically coexist and grow within a territory (Fonseca, 2018). These types of wealth are human, intellectual, environmental-natural, public-institutional, and private. It is important to note that, if these types of wealth have a similar growth, it is possible to achieve virtuous cycles; whereas if the growth is different between them or inexistant for any, we arrive at a vicious cycle (Fonseca et al., 2016).

\section{METHODS AND MATERIALS}

We analyzed the result of using the IDTS in all of the municipalities and departments in Colombia by applying the principal component analysis. The instrument was applied after redefining the key concepts mentioned below:

- Human wealth differs form the Human Development Index (health, education, and purshasing power) in that the first one combines the index factor with the social environment in which people dwell and develop physically, mentally, and socially. In other words, it considers that both happiness and welfare happen within the community, be it in the household, at work, or 
in public spaces (Carmona \& Díaz, 2018). Moreover, it is necessary to consider factors related with social and cultural diversity (Delgado \& García, 2019), in addition to what is already being done by other sectors, such as reducing mortality (healthcare sector), teaching and training the citizens (education sector), and providing opportunities that guarantee access to goods and services.

- Intellectual wealth refers to the ways in which knowledge is built, be it as critical and creative thinking and a generator of added value to the production of goods and services that guarantee welfare and quality of life (Rojas, 2019). The first way corresponds to conventional generation of academic/scientific knowledge that comes from science and research; the second one is related to the social ability to apply such knowledge; and the third one is open, popular, and ancestral knowledge, which emphasizes on a collaborative, participative, caring, and supportive coexistence.

- Environmental and natural wealth includes aspects such as forest coverage, body of water, soil characteristics, and biodiversity. This also includes the risk of avalanches, floods, and earthquakes, all of them regarded as the expresion of the relationship between society an the ecosystems (Naranjo, 2017).

- Public/institutional wealth can be divided in two types: tangible and intangible. Tangible public wealth includes investment in public services, road infrastructure, mobility, public works, among others. On the other hand, intangible public wealth refers to institutional performance, efficiency, transparency, etc., which facilitate participation and collaboration from the citizenship and ensure justice and security or conversely facilitate illegal activities (Calle-García et al., 2017).

- Private wealth is related to the people's capability to generate income and be employed, either for internal or external consumption. It includes aspects such as corporate diversity and density, GDP, qualified human capital, market, and product diversity (Carroll, 1991).

The Moran index was applied to the principal component analysis (PCA) to determine the existence or inexistence of clusters. Regressions were also used to establish the model's sensitivity to geographical control variables such as average distance to capital departments, or average distance to ports like Buenaventura or Cartagena.

Programming in $\mathrm{R}$ was used to perform the statistical testing, while information tables were built in Excel. The raw data were processed for each variable so that their value was positive and tending to 1 .

The final estimation for the IDTS considered the explicative weight each variable had in each type of wealth and their theorical and philosophical significance for each department and municipality. Each of these weights represent their variance contribution (VC). 


\section{RESULTS}

60 variables were selected and grouped into the five types of wealth by applying statistical and spatial methods such as the Moran index and clustering. Regression analysis with geographical control variables was also used.

The results for each of the types of wealth are shown below. They are presented as a consolidation for departments and municipalities.

Table I. Human wealth in municipalities and departments of Colombia (2000-2010)

\begin{tabular}{|c|c|c|c|c|}
\hline Factor & Index & Mun. & Departm. & Source \\
\hline \multirow{9}{*}{ Context } & \multirow{2}{*}{ Solution multidimensional poverty } & \multirow{2}{*}{32,97} & \multirow{2}{*}{23,1} & Departamento Administrativo \\
\hline & & & & Nacional de Estadística (DANE) \\
\hline & Receptivity of displaced people & 10,57 & 14,97 & DANE \\
\hline & Attraction by Opportunities & 10,42 & 2,65 & DANE \\
\hline & \multirow{2}{*}{ Gender equality } & & \multirow{2}{*}{9,7} & Departamento Nacional de \\
\hline & & & & Planeación (DNP) \\
\hline & Education coverage & & 27,23 & Education Ministry \\
\hline & \multirow{2}{*}{ Climate preference } & \multirow{2}{*}{24,6} & \multirow{2}{*}{22,35} & Instituto de Hidrología, Meteorología \\
\hline & & & & y Estudios Ambientales (IDEAM) \\
\hline \multirow{4}{*}{ Individual } & Nutrition & 21,44 & 24,3 & DANE \\
\hline & Gained life & & 3,22 & Health Ministry \\
\hline & Child vitality & & 37,26 & Health Ministry \\
\hline & Life expectancy at birth & & 35,22 & Health Ministry. \\
\hline
\end{tabular}

Source: (Fonseca et al., 2016). 
Table II. Intellectual wealth in municipalities and departments of Colombia (2000-2010)

\begin{tabular}{|c|c|c|c|c|}
\hline Type & Index & Mun. & Depart. & Source \\
\hline \multirow{16}{*}{$\begin{array}{l}\text { Academic } \\
\text { / scientific }\end{array}$} & Scientific knowledge of biodiversity & 8,79 & 0,12 & Von Humboldt \\
\hline & \multirow{2}{*}{ Professional intensity } & \multirow{2}{*}{49,24} & & Education \\
\hline & & & & Ministry \\
\hline & \multirow{2}{*}{ "Saber 11" } & \multirow{2}{*}{41,95} & & Education \\
\hline & & & & Ministry \\
\hline & Researcher density & & 18,58 & Colciencias \\
\hline & Research groups density & & 18,53 & Colciencias \\
\hline & \multirow{2}{*}{ Professional density } & & \multirow{2}{*}{3,84} & Education \\
\hline & & & & Ministry \\
\hline & \multirow{2}{*}{ Enrollment higher educ. institutions } & & \multirow{2}{*}{17,23} & Education \\
\hline & & & & Ministry \\
\hline & \multirow{2}{*}{ Postgraduate density } & & \multirow{2}{*}{18,75} & Education \\
\hline & & & & Ministry \\
\hline & Invest. in STI activities (intensity) & & 3,27 & Colciencias \\
\hline & Intellectual production & & 18,48 & Colciencias \\
\hline & Exports sophistication & & 0,74 & $\begin{array}{l}\text { Commerce, Industry } \\
\text { and Tourism Ministry }\end{array}$ \\
\hline \multirow{12}{*}{$\begin{array}{c}\text { Entrepre nurial } \\
\text { Industrial }\end{array}$} & \multirow{2}{*}{ Agricultural diversity } & \multirow{2}{*}{21,81} & & Unidad de Planificación \\
\hline & & & & Rural Agropecuaria (UPRA) \\
\hline & Agricultural productivity & 40,87 & & UPRA \\
\hline & Agricultural profitability & 37,32 & & UPRA \\
\hline & \multirow{2}{*}{ Business diversity } & & \multirow{2}{*}{15,67} & Commerce \\
\hline & & & & Chamber \\
\hline & \multirow{2}{*}{ Business density } & & \multirow{2}{*}{22,28} & Commerce \\
\hline & & & & Chamber \\
\hline & Technical and technological density & & 21,81 & DANE \\
\hline & Exports intensity & & 18,23 & T:I.T.Min \\
\hline & \multirow{2}{*}{ "Saber 11" } & & \multirow{2}{*}{22,01} & Education \\
\hline & & & & Ministry \\
\hline \multirow{5}{*}{$\begin{array}{c}\text { Ancestral/ } \\
\text { rural }\end{array}$} & \multirow{2}{*}{ Ethnic diversity } & \multirow{2}{*}{50} & \multirow{2}{*}{30,69} & Interior \\
\hline & & & & Ministry \\
\hline & \multirow{2}{*}{ Territorial complexity } & \multirow{2}{*}{50} & \multirow{2}{*}{29,99} & Instituto Geográfico \\
\hline & & & & Agustín Codazzi (IGAC) \\
\hline & Ancestral wisdom & & 39,32 & Interior Ministry \\
\hline
\end{tabular}

Source: (Fonseca et al., 2016). 
Regional Intellectual Wealth and Sustainable Development in Colombia

F. Fonseca, J. García y P. García

Table III. Natural/environmental wealth in municipalities and departments of Colombia (2000-2010)

\begin{tabular}{|c|c|c|c|c|}
\hline Factor & Index & Mun. & Dept. & Source \\
\hline & Proper land use & 29,5 & 23,38 & IGAC \\
\hline \multirow{4}{*}{ Attribute } & Economic intensity & 33,16 & 34,02 & DANE \\
\hline & Forest cover & 37,34 & & IDEAM \\
\hline & Natural protected areas & & 32,9 & Environmental Ministry \\
\hline & Non-renewable resources (intensity) & & 9,7 & DANE \\
\hline \multirow{5}{*}{ Risk } & Seismic sustainability & 9,41 & 19,88 & $\begin{array}{c}\text { Unidad Nacional para la } \\
\text { Gestión del Riesgo de Desastres } \\
\text { (UNGRD) }\end{array}$ \\
\hline & Flooding, landslide, avalanches sust. & 46,16 & 22,27 & UNDGRD \\
\hline & Mining sustainability & 32,23 & & Energy Ministry \\
\hline & Forest and water cover & & 22,78 & IDEAM \\
\hline & Forest sustainability & 12,1 & 35,07 & IDEAM \\
\hline
\end{tabular}

Source: (Fonseca et al., 2016).

Table IV. Public wealth in municipalities and departments of Colombia (2000-2010)

\begin{tabular}{|c|c|c|c|c|}
\hline Factor & Index & Mun. & Dept. & Source \\
\hline \multirow{7}{*}{ Tangible } & Road density & 29,34 & 12 & Transport Ministry \\
\hline & Internet broadband & 29,26 & 19,36 & ICT Ministry \\
\hline & Rural property equity & 7,79 & 11,37 & IGAC \\
\hline & Electric energy coverage & & 21,28 & Energy Ministry \\
\hline & Water supply reliability & 16,66 & 19,93 & Housing Ministry \\
\hline & Solid waste integral management & 16,94 & 4,77 & Housing Ministry \\
\hline & Passengers by air & & 1,29 & $\begin{array}{l}\text { Civil Aviation } \\
\text { Authority of Colombia }\end{array}$ \\
\hline \multirow{11}{*}{ Intangible } & Municipal performance & 15,84 & & DNP \\
\hline & Open government & 16,23 & 16,98 & Comptrollers \\
\hline & Conviviality & 16,38 & 7,42 & Defence Ministry \\
\hline & Absence of illegal armed groups & 16,21 & 1,95 & Defence Ministry \\
\hline & Electoral transparency & 15,98 & 7,01 & $\begin{array}{l}\text { Consultoría para los derechos } \\
\text { humanos y el desplazamiento }\end{array}$ \\
\hline & Electoral participation & 15,89 & & CODHES \\
\hline & Voluntary work participation & 3,48 & 10,33 & DANE \\
\hline & Risk management & & 19,39 & DNP \\
\hline & Institutional performance & & 14,31 & DNP \\
\hline & Formal justice & & 17,4 & Justice Ministry \\
\hline & Alternative justice mechanisms & & 5,2 & Justice Ministry \\
\hline
\end{tabular}

Source: (Fonseca et al., 2016). 
Table V. Private wealth in municipalities and department of Colombia (2000-2010)

\begin{tabular}{clccc}
\hline \multirow{2}{*}{ Factor } & \multicolumn{1}{c}{ Index } & Mun. & Dept. & Source \\
\hline & GDP intensity & 58,11 & 9,38 & DANE \\
\cline { 2 - 5 } Internal Markets & Cadastral value & 27,75 & 13,68 & IGAC \\
\cline { 2 - 5 } & Cadastral productivity & 14,15 & & IGAC \\
\cline { 2 - 5 } & Business density & 25,41 & Commerce Chamber \\
\cline { 2 - 5 } & Productive diversity & 10,72 & UPRA \\
\cline { 2 - 5 } & Intradepartmental flow & 20,77 & DANE \\
\cline { 2 - 5 } Exports & Financial services & 20,04 & Consejo Privado de \\
& Int. Market diversification & 43,05 & CPC \\
\cline { 2 - 5 } & Commodities Diversification & 39,81 & CPC \\
\cline { 2 - 4 } & Cadastral productivity & 17,14 & IGAC \\
\hline
\end{tabular}

Source: (Fonseca et al., 2016).

During the PCA analysis, we found that almost all the variables both at the municipal and departmental levels are sensitive to the selected control variables.

In the same way, even when some indexes show encouraging numbers, particularly those related to public or private healthcare and education, others are insufficient, like those related to environmental protection, or investment in science, technology, and innovation, as well as to institutional healthcare.

On the other hand, with PCA we determined that four out of the five types of wealth are growing (human, intellectual, public, and private). However, this growth is at the expense of the natural and environmental wealth, which poses a problem in terms of sustainability.

In other words, Colombian development is happening with considerably high natural and environmental costs, which increases risks for people, particularly if one considers risks related to seismic activity, avalanches, and floods. This shows that this development is environmentally unsustainable.

\section{CONCLUSIONS}

Classic works in the field of economics have considered multiple factors and perspectives in the study of development and welfare (Smith, 1776, Singer, 1952, Lucas, 1989, Azariadis \& Drazen, 1990, Meier \& Rauch, 1995, Schumpeter et al., 2003). However, the environmental perspective has only 
recently started to be considered (Gómez-Contreras, 2014), particularly considering the differentiated and sometimes contradictory effect of human groups (Foladori, 1999, Granato et al., 1996).

This study works with the hypothesis that development is a complex process, which occurs in different dimensions and heterogeneous scales. Because of that, one must consider a dynamic perspective to achieve both individual and collective welfare, which brings a responsible use of wealth into consideration. It is also necessary to strengthen people's capabilities and skills in the use of available wealth, especially because the Anthropocene, as both a socio-ecological and social decision-making system, helps to comprehend the needs and expectations of the people (Fonseca-Zárate et al., 2020).

The importance of knowledge, innovation, the environmental and socio-ecological perspective has only recently been considered ( 80 's) to be fundamental for the right to a "good" development of countries and regions. (Fonseca, 2018) recalls that development is a complex, multidimensional, multi-spatial process that involves identifying, agreeing, and achieving society's goals and expectations. He proposes IDTS as a different approach to assess "sustainability" by observing the coincidence or opposition of the five wealth vectors using the PCA statistical tool and the observation of the distance between their individual values.

Consequently, the processed information showed that:

1. Colombia is indeed growing, but at the expense of its natural resources and ecosystems, thus increasing the risk for its population. This is a common pattern in Latin America (Galindo et al., 2014).

2. As the IDTS value increases for the municipalities, the variance, namely the distance between the five types of wealth increases, as does their unbalance. These unbalances can become negative and generate a vicious cycle, as is the case of water access, poverty, and other global economic indexes (Correa, 2017).

3. The directions of natural and intellectual wealth are opposite, that is, science and technology are uncoordinated and irresponsive to biodiversity and the country's climate variety. This constitutes evidence of what the literature has stated in relation to the need to stimulate, as a priority, the articulation and development of scientific and technological investigation capabilities (Duarte \& Velho, 2009).

4. Some municipalities are far away from the country's capital and this fact appears to create a vicious cycle in terms that it does not allow the wealth to homogeneousincrease and as so, the welfare levels that are achieved are not stable; it is worst in remote territories.

Therefore, it is really important to modify the existing exploitation model (García-Ubaque, 2016) and contribute to decreasing the distance between the five types of wealth. This will require much more science and technology, particularly in fields related to engineering and social and institutional innovation, which must be closely related to understanding our mega- biodiversity and socioecological complexity. 


\section{FUNDING}

This study was funded with the researchers' own resources.

\section{REFERENCES}

[Azariadis \& Drazen, 1990] Azariadis, C. \& Drazen, A. (1990). Threshold Externalities in Economic Development. The Quarterly Journal of Economics, 105(2), 501-526. https : / / doi . org/10.2307/ $2937797 \uparrow$ Ver página 22

[Calle-García et al., 2017] Calle-García, A. J., Calle-García, J. S., \& Yoza-Rodríguez, N. R., (2017). Modelo de articulación universidad y actores territoriales para el desarrollo local de la provincia de Manabí-Ecuador. DELOS: Desarrollo Local Sostenible, 10(29), 2. https : / / doi . org/10 . 37117 / S.v1i10.101 个Ver página 18

[Carmona \& Díaz, 2018] Carmona, N. \& Díaz, M. (2018). El desarrollo socioeconómico en Latinoamérica. Un análisis a la luz de los objetivos de desarrollo sostenible de las Naciones Unidas. Atlantic Review of Economics: Revista Atlántica de Economía, 1(1), 1-19. https : / dialnet . unirioja.es / servlet/articulo?codigo=6525199 $\uparrow$ Ver página 18

[Carroll, 1991] Carroll, A. (1991). The pyramid of corporate social responsibility: Toward the moral management of organizational stakeholders. Business Horizons, 34(4), 39-48. https : / / do i . org / $10.1016 / 0007-6813$ (91) 90005-G $\uparrow$ Ver página 18

[Castells \& Himanen, 2016] Castells, M. \& Himanen, P. (2016). Reconceptualización del Desarrollo en la Era Global de la Información. Fondo de Cultura Económica Chile. $\uparrow$ Ver página 16

[Correa, 2017] Correa, G. (2017). Acceso al agua, pobreza y desarrollo en Colombia. Revista de la Universidad de la Salle, 72, 27-46. https://ciencia.lasalle.edu.co/cgi/viewcontent. cgi?article=1516\&context=ruls $\uparrow$ Ver página 23

[Costanza et al., 2014] Costanza, R., De Groot, R., Sutton, P., Van der Ploeg, S., Anderson, S., Kubiszewski, I., Farber, S, \& Turner, K. (2014). Changes in the Global Value of Ecosystem Services. Global Environmental Change, 26, 152-158. https://doi.org/10.1016/j.gloenvcha.2014. $04.002 \uparrow$ Ver página 17

[Dasgupta, 2013] Dasgupta, P. (2013). The nature of economic development and the economic development of nature. University of Cambridge https://doi.org/10.2139/ssrn.2352914 个Ver página 17 
[Delgado \& García, 2019] Delgado, J. \& García, J. (2019). La Innovación social como herramienta del desarrollo local. Una aproximación para América Latina. Propuestas para el Desarrollo, III(1), 77-94. https: / / www ·propuestasparaeldesarrollo.com/index.php/ppd/ article/view/ $67 \uparrow$ Ver página 18

[Duarte \& Velho, 2009] Duarte, O. \& Velho, L. (2009). Capacidades científicas y tecnológicas de Colombia para adelantar prácticas de bioprospección. Revista Iberoamericana de Ciencia, Tecnología y Sociedad-CTS, 4(12), 55-68. http://www.revistacts.net/contenido/numero-12/ capacidades-cientificas-y-tecnologicas-de-colombia-para-adelantar-prac ticas-de-bioprospeccion/ $\uparrow$ Ver página 23

[Escobar, 2008] Escobar, A. (2008). La Invención del Tercer Mundo. Fundación Editorial el Perro y la Rana. $\uparrow$ Ver página 17

[Foladori, 1999] Foladori, G. (1999). Sustentabilidad ambiental y contradicciones sociales. Ambiente E Sociedade, 2(5), 19-34. https: / / doi .org/10.1590/S1414-75381999000200003 个Ver página 23

[Fonseca et al., 2016] Fonseca, C., Castellanos, F., \& Castillo, S. (2016). IDTS (Índice de Desarrollo Territorial Sustentable): Instrumentos para la Gestión eficaz de la Paz completa y el Desarrollo verdadero. Administración y Desarrollo. $\uparrow$ Ver página 17, 19, 20, 21, 22

[Fonseca, 2018] Fonseca-Zárate, C. H. (2018). Lineamientos y métodos de construcción y evaluación de políticas y estrategias de ciencia, tecnología e innovación diferenciadas regionalmente para el desarrollo territorial sustentable de Colombia. UPTC-IGAC. $\uparrow$ Ver página 17, 23

[Fonseca-Zárate et al., 2020] Fonseca-Zárate, C. H., García-Ubaque, J. C., \& García-Benitez, P. F. (2020). Collective Intuition and Alternative Statistics to Hit. Tecnura, 24(63), 57-67. https : / / doi . org/10.14483/22487638.16197 个Ver página 23

[Galindo et al., 2014] Galindo, L., Samaniego, J., Alatorre, J., Ferrer, J., \& Reyes, O. (2014). Paradojas y riesgos del crecimiento económico en América Latina y el Caribe: Una visión ambiental de largo plazo (vol. 156, Serie Medio Ambiente y Desarrollo). CEPAL. $\uparrow$ Ver página 23

[García-Ubaque, 2016] García-Ubaque, C. (2016). Editorial. Tecnura, 20(48), 11-12. https:// doi . org/10.14483/22487638.10567 个Ver página

[Gómez-Contreras, 2014] Gómez-Contreras, J. (2014). Del desarrollo sostenible a la sustentabilidad ambiental. Revista de la Facultad de Ciencias Económicas: Investigación y Reflexión, 22(1), 115-136. https://doi.org/10.18359/rfce.643个Ver página 23 
[Granato et al., 1996] Granato, J., Inglehart, R., \& Leblang, D. (1996). The Effect of Cultural Values on Economic Development: Theory, Hypotheses, and Some Empirical Tests. American Journal of Political Science, 40(3), 607-631. https: / / doi .org/10.2307/2111786 †er página 23

[Hausmann, 2006] Hausmann, R. (2006 ). Development Revisited. Harvard. $\uparrow$ Ver página 17

[Krugman, 2011] Krugman, P. (2011). The New Economic Geography, Now Middle Aged. Regional Studies, 45(1),1-7. https: / / doi.org/10.1080/00343404.2011.537127个Ver página 17

[Lucas, 1989] Lucas, R. E. (1989). On the mechanics of economic development. NBER Working Paper, R1176. https://ssrn.com/abstract=227120 个Ver página 17, 22

[Meier \& Rauch, 1995] Meier, G. M. \& Rauch, J. E. (1995). Leading issues in economic development (vol. 6). Oxford University Press. $\uparrow$ Ver página 22

[Naranjo, 2017] Naranjo, L. (2017). Ecosistemas del Antropoceno en Colombia. En D. Pérez, \& S. Restrepo, En diálogo con la tierra. Por una Colombia sostenible. Bogotá: Editorial Universidad del Rosario. $\uparrow$ Ver página 18

[Ocampo, 2021] Ocampo, J. (2021). Políticas Económicas para la gestión ambiental. Bogotá: FESCOL. Raworth, K. (2014). The Doughnut Economics. $\uparrow$ Ver página 17

[Raworth, 2014] Raworth, K. (2014). The Doughnut Economics. $\uparrow$ Ver página 17

[Rojas, 2019] Rojas, J. (2019). El Capital Intelectual y el Conocimiento: Generando Ventajas Competitivas en las Empresas. Revista Sinergia, 1(5), 160-168. $\uparrow$ Ver página 18

[Romer,1986] Romer, P. (1986). Increasing returns and long-run growth. The Journal of Political Economy, 94(5), 261420. https://doi.org/10.1086/261420 ^er página 17

[Selomane et al., 2019] Selomane, O., Reyers, B., Bigss, R., \& Hamann, M. (2019). Harnessing Insights from Social- Ecological Systems Research for Monitoring Sustainable Development. Sustainability, 11(4), 1190. https: / /doi.org/10.3390/su11041190 个er página 17

[Sen, 2001] Sen, A. (2001). Desarrollo como libertad. Fondo Cultura Económica. $\uparrow V e r$ página 16

[Shindell, 2015] Shindell, D. T. (2015). The social cost of atmospheric release. Economics Discussion Papers, 56, 85245. http: // hdl. handle. net/10419/85245 个er página 17

[Schumpeter et al., 2003] Schumpeter J. \& Backhaus U. (2003). The Theory of Economic Development. In Backhaus, J. \& Schumpeter, J. (Eds.) The European Heritage in Economics and the Social Sciences (vol 1). Springer. $\uparrow$ Ver página 22 
[Singer, 1952] Singer, H. W. (1952). The Mechanics of Economic Development: A Quantitative Model Approach. Indian Economic Review, 1(2), 1-18. https://www.jstor.org/stable/45149613 个Ver página 22

[Smith, 1776] Smith, A. (1776). An inquiry into the nature and causes of the wealth of nations. W. Strahan and T. Cadell. https://doi.org/10.1093/oseo/instance.00043218 个Ver página 22

[Spaiser et al., 2017] Spaiser, V., Ranganathan, S., Bali Swain, R., \& Sumpter, D. (2017). The sustainable development oxymoron: quantifying and modelling the incompatibility od sustainable development goals. International Journal of Sustainable Development \& Wolrd Ecology, 24(6), 457-470. https://doi.org/10.1080/13504509.2016.1235624 个Ver página 17

[Stiglitz, 2002] Stiglitz, J. H. (2002). Globalization and its Discontents (H. Rodríguez-Braun, Trans.). Taurus. $\uparrow$ Ver página 17

[Villegas et al., 2017] Villegas, E., Hernández, M., \& Salazar, B. (2017). La medición del capital intelectual y su impacto en el rendimiento financiero en empresas del sector industrial en México. Contaduría y administración, 62(1), 184-206. https://doi.org/10.1016/j.cya.2016.10.002个Ver página 